\title{
Model Pembelajaran Talking Stick Melalui Permainan Truth or Dare Pada Tari Bungong Jeumpa Kelas IV Sekolah Dasar
}

\author{
Arina Restian ${ }^{\mathrm{a}, 1^{*}}$, Abdurrohman Muzakki ${ }^{\mathrm{b}, 2}$, Wahyu Intan Purnamasari $\mathrm{i}^{\mathrm{c}, 3}$ \\ abc Universitas Muhammadiyah Malang, Jalan Raya Tlogomas 256, Malang, Indonesia, 65144 \\ ${ }^{1}$ arina.poenya@gmail.com; ${ }^{2}$ muzakki@umm.ac.id; ${ }^{3}$ wahyuintan307@gmail.com \\ ${ }^{*}$ Corresponding Author
}

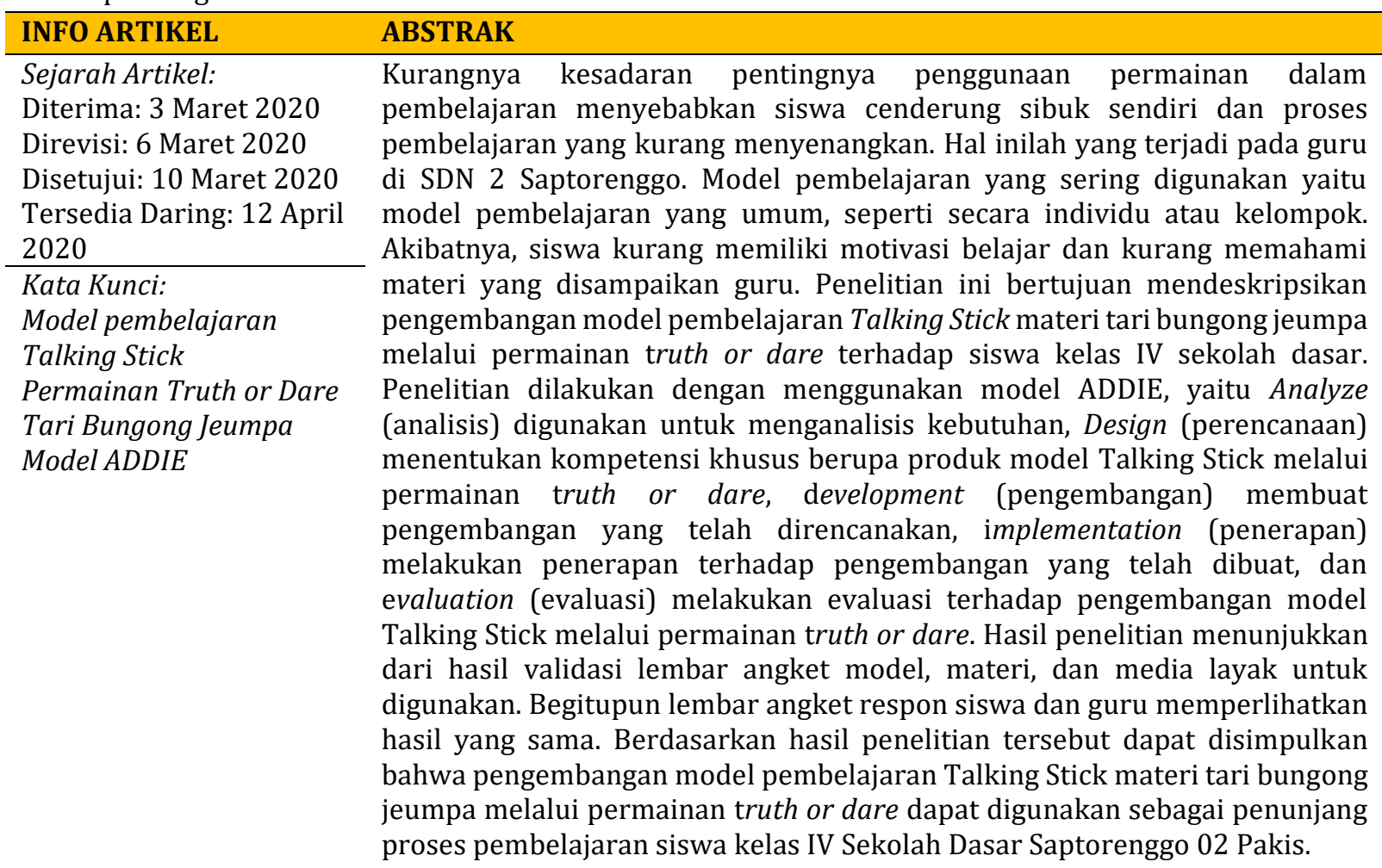

\begin{tabular}{ll}
\hline & ABSTRACT \\
\hline $\begin{array}{l}\text { Keywords: } \\
\text { Talking Stick learning }\end{array}$ & Lack of awareness of the importance of using games in learning causes \\
modern & students to tend to be busy on their own and the learning process is less fun. \\
Truth or dare games & This is what happened to teachers at 02 Saptorenggo State Elementary School \\
Bungong Jeumpa dance & Pakis. Learning models that are often used are general learning models, such \\
ADDIE model & as individually or in groups. As a result, students lack motivation to learn and \\
& lack understanding of the material delivered by the teacher. This study aims \\
& to describe the development of the Talking Stick learning model for the \\
& bungong jeumpa dance material through the game truth or dare for grade IV \\
& elementary school students. The study was conducted using the ADDIE model, \\
& namely Analyze used to analyze the needs, Design determine the specific \\
& competencies in the form of Talking Stick model products through the game \\
& truth or dare, development to make the planned development, \\
& implementation to do the application of the development that has been made, \\
& and evaluation evaluates the development of the Talking Stick model through \\
& the game truth or dare. The results showed that the results of the \\
& questionnaire sheets of models, materials, and media were eligible to be used. \\
Likewise, the questionnaire sheets of student and teacher responses show the
\end{tabular}


same results. Based on these results it can be concluded that the development of the learning model of Talking Stick dance material bungong jeumpa through the truth or dare game can be used as a support to the learning process of grade IV students at 02 Saptorenggo State Elementary School Pakis.

(C) 2020, Restian, Muzakki, \& Purnamasari This is an open access article under CC-BY license

How to Cite: Restian, A., Muzakki, A., \& Purnamasari, W. I. (2020). Model Pembelajaran Talking Stick Melalui Permainan Truth or Dare Pada Tari Bungong Jeumpa Kelas IV Sekolah Dasar. JURNAL SATWIKA, 4 (1), 1-9 doi: https://doi.org/10.22219 /SATWIKA.Vol4.No1.1-9

\section{Pendahuluan}

Pendidikan merupakan program atau proses untuk mengembangkan dan membangkitkan potensi dalam diri seseorang sejak dini melalui ikatan batin (orang tua terhadap anak), kebiasaan sehari-hari, pengalaman, dan lembaga (Nurkholis, 2013). Pendidikan dapat menghasilkan karakter dan ilmu pengetahuan atau kecerdasan pikiran. Menurut Undang-Undang Republik Indonesia nomor 20 tahun 2003 tentang sistem pendidikan nasional dinyatakan pendidikan adalah kegiatan yang direncanakan untuk mewujudkan proses belajar secara aktif yang dilakukan oleh peserta didik dalam menggali potensi dirinya mencakup tentang spiritual keagamaan, pengendalian diri, kepribadian, kecerdasan, akhlak mulia, serta keterampilan kebutuhan bagi dirinya, masyarakat, bangsa dan negara (Sundari, 2016).

Peran pendidik sangatlah penting dalam pembelajaran. Pendidik adalah seseorang atau lebih yang bertanggung jawab dalam proses pendidikan atau pengetahuan peserta didik (Ahmadi, 2014). Proses peserta didik memperoleh pengetahuan dapat dilakukan di sekolah, rumah, atau masyarakat. Pihak yang bertanggung jawab terlaksananya pendidikan di sekolah adalah guru. Di rumah orang tua juga berperan penting dalam pendidikan, karena pendidikan yang didapat oleh peserta didik atau siswa pertama kali dilakukan oleh orang tua.

Peserta didik merupakan subjek belajar yang dituntut mampu mengingat, memahami, menerapkan apa yang dipahami, menganalisis masalah dan menyimpulkan masalah. Keterampilan siswa atau peserta didik dapat diwujudkan melalui keaktifan siswa dalam merespon mata pelajaran. Salah satu mata pelajaran di mana siswa dituntut untuk aktif dan kreatif adalah mata pelajaran Seni Budaya dan Prakarya atau SBdP.

Seni Budaya dan Prakarya atau SBdP salah satu mata pelajaran wajib dalam kurikulum 2013. Seni Budaya dan Prakarya merupakan mata pelajaran yang mempelajari budaya bangsa Indonesia dan prakarya atau membuat karya seni yang dapat melatih kreativitas peserta didik atau siswa. Pembelajaran Seni Budaya dan Prakarya yang dilakukan di sekolah dapat menggunakan pendekatan tematik atau pendekatan saintifik. Pendekatan saintifik meliputi 5M, yaitu mengamati, menanya, mengassosiasi, mempraktikkan, dan memproses atau menyimpulkan (Susilana, 2014). Oleh karena itu, pendidik harus memiliki perbekalan pengetahuan Seni Budaya yang ada di Indonesia agar peserta didik dapat memanfaatkannya sebagai kegiatan apresiasi dan kreasi (Permanasari, Lestari, \& Fujiawati, 2018). Dia ntara berbagai keragaman budaya yang dimiliki bangsa Indonesia salah satunya adalah seni tari.

Seni tari merupakan olah gerak tubuh yang memiliki estetika, makna, dan tujuan yang ingin disampaikan dari setiap gerakan. Seni tari memiliki daya tarik yang cukup besar di lingkungan sekolah (Arisyanto, Sundari, \& Untari, 2018). Salah satu tari yang dimuat dalam mata pelajaran Seni Budaya dan Prakarya pada kelas IV Sekolah Dasar merupakan tari bungong jeumpa. Tari 
bungong jeumpa berasal dari Aceh dan memiliki variasi gerak yang melibatkan tangan, kaki, badan, dan pinggul yang diiringi musik melayu (Priyani, 2019). Dalam penyampaian materi, pendidik perlu memperhatikan pemilihan model pembelajaran yang akan digunakan.

Model pembelajaran adalah pola kegiatan yang dirancang secara sistematis yang digunakan untuk panduan dalam kegiatan pembelajaran sehingga tercapainya tujuan pembelajaran. Model merupakan suatu struktur yang memiliki konsep dan mencangkup empat bentuk, antara lain konseptual, prosedural, visual, dan rumus atau persamaan (Atwi, 2014). Di dalam model pembelajaran memiliki macammacam model yang dapat digunakan secara individu maupun kelompok atau klasikal. Model pembelajaran secara kelompok disebut juga dengan model pembelajaran kooperatif atau cooperative learning. Dalam model kooperatif yang akan dibahas dalam penelitian ini adalah model pembelajaran kooperatif tipe Talking Stick.

Talking Stick merupakan model pembelajaran yang memiliki ciri khas, yaitu menggunakan tongkat sebagai media pembelajaran. Model Talking Stick memiliki langkah-langkah dalam penerapannya, antara lain (1) guru menyiapkan sebuah tongkat sebelum kegiatan pembelajaran dilakukan, (2) guru menyapikan materi, (3) siswa melakukan tanya jawab kepada guru berkaitan materi yang belum dipahami, (4) guru memberikan kesempatan untuk siswa mempelajari lagi apa yang telah dibahas, (5) guru mempersilahkan siswa untuk menutup buku, (6) guru mengambil tongkat dan memberikan kepada siswa, (7) guru memainkan musik dan saat musik dimainkan tongkat tersebut berjalan dengan cara siswa yang memegang tongkat memberikan tongkat tersebut kepada temannya, dan seterusnya seperti itu sampai musik berhenti (Hamzah, 2013). Saat salah satu siswa memegang tongkat kemudian musik berhenti, siswa tersebut wajib menjawab pertanyaan yang diberikan oleh pendidik atau guru.
Model Talking Stick dapat dikembangkan melalui sebuah permainan, yaitu permainan truth or dare karena permainan ini dilakukan secara berkelompok atau klasikal. Permainan truth or dare merupakan permainan yang telah digandrungi sejak zaman dahulu di berbagai negara kecuali Indonesia, tetapi baru-baru ini permainan truth or dare merajalela di kalangan remaja, masyarakat, dan bahkan anak-anak. Dalam segi kata "truth" artinya kebenaran, dan "dare" berarti tantangan. Truth or dare adalah suatu permainan di mana pemain harus memilih salah satu antara truth atau dare.

Berdasarkan pengamatan penulis, proses pembelajaran seni budaya siswa kelas 4 di SDN Saptorenggo 02 Pakis memiliki sejumlah kelemahan. Proses pembelajaran yang dilakukan tidak menarik perhatian siswa dan membosankan. Dalam obervasi ditemukan ada sebagian siswa yang bermain sendiri saat kegiatan pembelajaran berlangsung. Siswa kurang fokus dalam mengikuti pembelajaran. Kurangnya variasi penggunaan model pembelajaran yang dilakukan oleh guru merupakan salah satu penyebabnya. Hasil observasi ini didukung oleh hasil wawancara pada 17 Januari 2020 kepada guru mata pelajaran. Guru menyatakan hanya menerapkan model pembelajaran itu-itu saja, dalam artian kurangnya variasi penggunaan model pembelajaran yang dilakukan oleh guru sehingga siswa kurang aktif dan fokus pada saat pembelajaran, dan tidak tersedianya permainan dalam penyampaian pembelajaran atau materi. Bahkan ketika model Talking Stick digunakan dalam pembelajaran, peneliti menemukan beberapa kendala, yaitu (1) ketika pembelajaran berlangsung, siswa merasa bosan mereka akan bermain sediri atau menjaili temannya, (2) siswa yang terpilih atau mendapat tongkat saat berhenti hanya beberapa saja, (3) terjadinya kegiatan yang kurang kondusif, karena siswa bergurau dan saling lempar tongkat.

Berdasarkan hal tersebut diperlukan pengembangan model Talking Stick dalam pembelajaran seni budaya siswa kelas 4 SDN 
02 Saptorenggo Pakis. Peneliti melakukan pengembangan model Talking Stick melalui permainan truth or dare. Pengembangan yang dilakukan yaitu musik yang diganti dengan dadu, agar siswa tidak melempar tongkat yang digunakan dan dipadukan dengan permainan karena karakteristik peserta didik yang suka bermain.

Berdasarkan penelitian yang dilakukan oleh Restian diperlihatkan bahwa kemampuan kolaboratif guru dan siswa dengan model pembelajaran yang menekankan keatifan dan menarik minat siswa dapat meningatkan minat siswa untuk belajar seni tari tradisional (Restian, 2016). Pembekalan kemampuan (skill) tari kepada siswa dapat menjadi modal yang bermanfaat bagi siswa. Selain itu hal ini juga dapat membentuk karakter nasionalisme, khususnya kecintaan terhadap kebudayaan Indonesia. Selain hal tersebut, pengembangan pembelajaran senantiasa diperlukan, baik oleh guru maupun peneliti, untuk terus meningkatkan proses pembelajaran yang berdampak pada meningkatnya pemahaman siswa terhadap materi yang diajarkan (Sunaryo, Andalas, Putra, \& Asrini, 2018).

Dengan demikian, penelitian ini bertujuan meningkatkan proses pembelajaran seni budaya, khususnya materi tari bungong jeumpa, pada siswa kelas 4 SDN 02 Saptorenggo Pakis agar proses belajar mengajar berjalan secara kondusif, melatih sikap siswa dalam bertanggung jawab, melatih percaya diri dalam menjawab atau melakukan tantangan yang telah ditentukan. Permainan Truth or Dare dapat dilakukan dalam mata pelajaran tematik maupun bukan tematik dengan tuntutan guru harus memperhatikan soal yang dapat digunakan untuk pertanyaan dan dapat digunakan untuk tantangan.

\section{Metode}

Penelitian pengembangan ini dilakukan dengan model ADDIE. Tahap analisis digunakan pada tahapan analisis awal dan analisi penelitian. Tahap analisis awal yang digunakan oleh peneliti untuk menganalisis adanya kebutuhan dalam pengembangan. Analisis yang dilakukan berkaitan dengan bahan ajar yang digunakan dalam proses belajar. Untuk menganalisis apa yang dibutuhkan, peneliti melakukan wawancara kepada salah satu guru wali kelas IV SDN Saptorenggo 02 Pakis pada tanggal 17 Januari 2020. Hasil wawancara memperlihatkan dalam penerapan model pembelajaran Talking Stick siswa yang mendapatkan giliran menjawab pertanyaan sangatlah sedikit, siswa melempar tongkat sebagai media dari model Talking Stick, musik yang digunakan dalam penerapan model tersebut sebagian siswa belum mengetahuinya. Dalam penyampaian materi tari bungong jeumpa, guru juga mendapatkan kesulitan, karena kurangnya kemampuan guru dalam kemampuan menari sehingga siswa mendapatkan kesulitan mengikuti pembelajaran.

Desain merupakan tahapan setelah peneliti melakukan analisis kebutuhan yang. Desain dilakukan untuk mengatasi masalah yang telah ditemukan. Peneliti membuat rencana dengan melakukan pengembangan model pembelajaran Talking Stick. Peneliti juga menyampaikan materi tari Bungong Jeumpa karena peneliti memiliki kemampuan dalam menari. Dalam kegiatan pembelajaran peneliti memadukan dengan permainan Truth or Dare. Kemudian, peneliti mempersiapkan alat dan bahan untuk menerapkan kegiatan pengembangan tersebut.

Pengembangan merupakan tahap untuk mengembangkan produk yang telah ada. Produk yang dikembangkan dalam penelitian ini adalah model pembelajaran Talking Stick sebagaimana masalah atau hambatan yang telah dijelaskan dan model Talking Stick menggunakan musik untuk menjalankan tongkat tetapi dalam penelitian ini menggunakan sebuah dadu. Dalam pengembangan ini digunakan untuk mengetahui pengembangan model Talking Stick melalui permainan Truth or Dare pada materi tari bungong jeumpa. Untuk mengetahui pengembangan peneliti membuat angket validasi yang akan 


\section{Jurnal Satwika : Kajian Ilmu Budaya dan Perubahan Sosial Vol. 4, No. 1, April 2020, 1-9}

divalidasi oleh ahli model, ahli media dan ahli materi. Validasi tersebut dilakukan untuk mengetahui kelemahan pengembangan model pembelajaran Talking Stick. Dalam permainan memuat mata pelajaran Seni Budaya dan Prakarya (SBdP) yaitu materi pokoknya Seni Tari dan dikhususkan pada tari Bungong Jeumpa. Deskripsi tampilan produk dalam pengembangan model pembelajaran Talking Stick, yaitu tongkat yang menjadikan ciri khas dari model pembelajaran Talking Stick. Tongkat tersebut dinamakan tongkat Bulyam (bulu ayam). Gambar 1 merupakan tongkat bulu ayam yang digunakan dalam permainan Talking Stick.

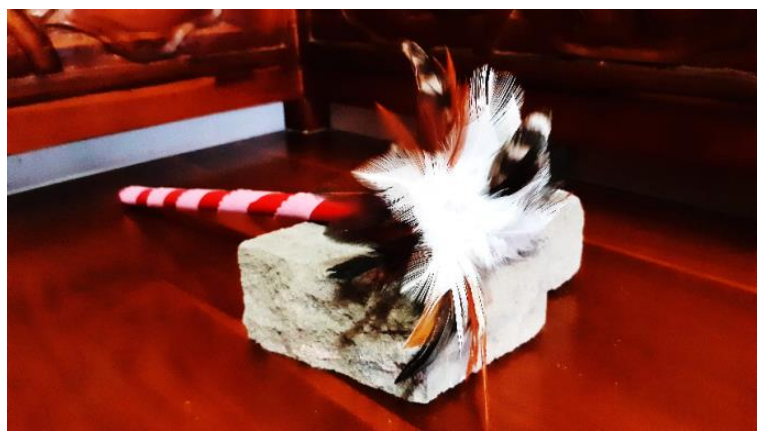

Gambar 1 Tongkat Bulyam (Sumber: Dokumentasi Peneliti 2020)

Pengembangan model pembelajaran Talking Stick yang awalnya menggunakan sebuah musik diganti dengan dadu. Dadu tersebut dinamakan Dadu Raksasa, karena ukurannya yang besar. Gambar 2 menunjukkan perubahan alat dan ukuran dari dadu yang digunakan dalam pembelajaran. Dadu tersebut digunakan sebagai pengganti musik. Selain dadu juga digunakan kartu permainan truth or dare seperti dalam Gambar 3 dan Gambar 4 .Kartu permainan ini memiliki ukuran panjang $10 \mathrm{~cm}$ dan lebar $6 \mathrm{~cm}$.

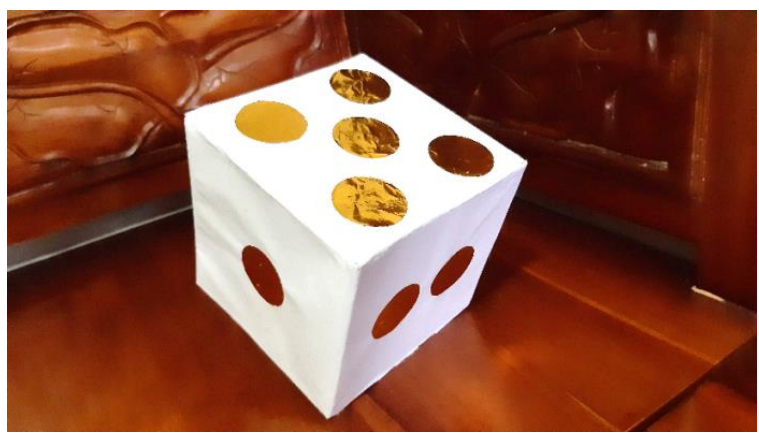

Gambar 2 Dadu Raksasa (Sumber: Dokumentasi Penulis, 2020)

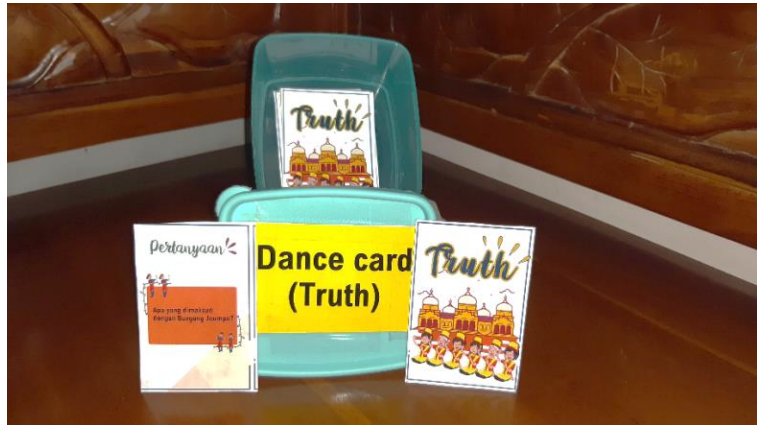

Gambar 3 Kartu Truth (Sumber: Dokumentasi Penulis, 2020)

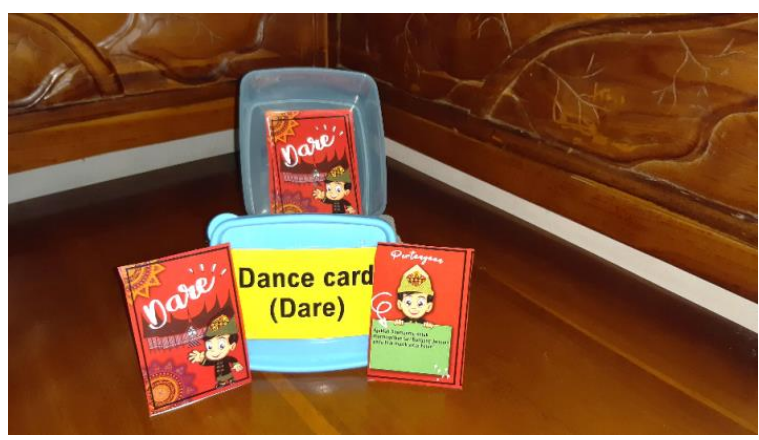

Gambar 4 Kartu Dare (Sumber: Dokumentasi Penulis, 2020)

Selain itu, juga digunakan botol berisikan kertas undian yang bersungsi sebagai pilihan dari truth atau dare (Gambar 5) yang akan didapat peserta permainan. Botol berisikan lotere diberinama Ambil Aku. Penamaan ini didasarkan pada sifat dari kertas-kertas lotere agar diambil oleh peserta yang terlibat dalam permainan. Di dalam lotere ini terdapat beragam pilihan pertanyaan yang harus diselesaikan oleh peserta permainan truth or dare.

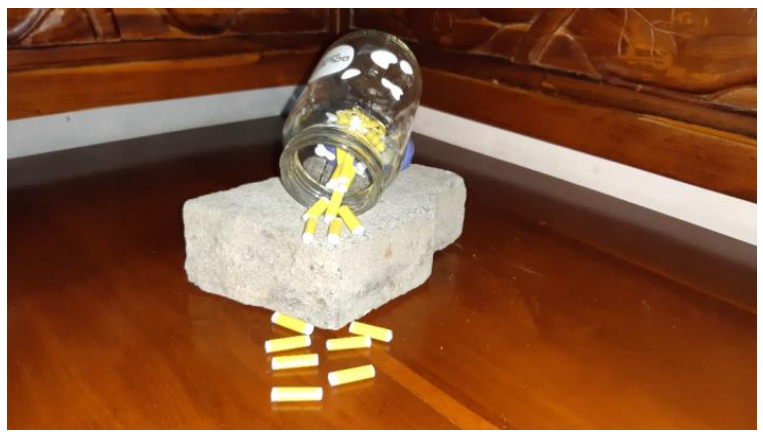

Gambar 5 Lotere yang Dinamakan Ambil Aku (Sumber: Dokumentasi Penulis, 2020) 
Sebagai panduan permainan, disusun buku petunjukan penggunaan permainan truth or dare yang telah dirancang (Gambar 6).

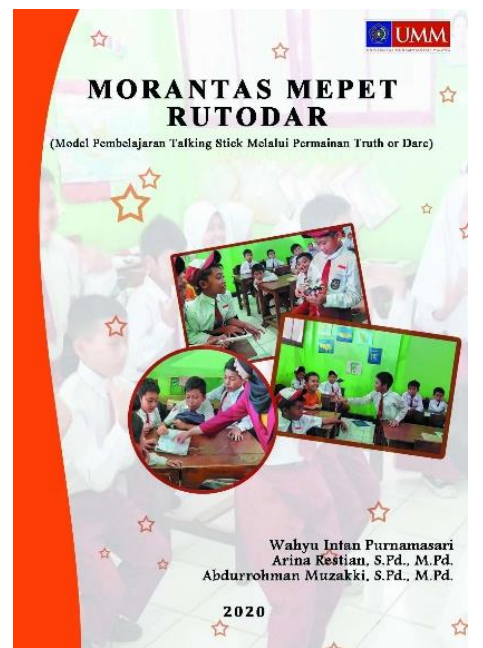

Gambar 6 Buku Petunjuk Permainan (Sumber: Dokumentasi Penulis, 2020)

Implementasi merupakan kegiatan penerapan terhadap apa yang telah dikembangkan dengan berpedoman pada analisis yang telah dilakukan. Pada kegiatan implementasi, peneliti mencatat dan mengamati apa saja kekurangan dan kelebihan saat kegiatan berlangsung. Setelah kegiatan dilakukan, peserta didik dan guru mendapatkan angket berkaitan dengan penerapan pengembangan model Talking Stick.

Evaluasi digunakan untuk mengetahui kekurangan dan kelebihan dalam penerapan pengembangan model pembelajaran Talking Stick yang dirancang. Evaluasi dibagi menjadi dua, yaitu evaluasi formatif dan evaluasi sumatif. Evaluasi formatif merupakan evaluasi yang terletak pada setiap tahapan, sedangkan evaluasi sumatif adalah evaluasi yang mencangkup keseluruhan yaitu mulai awal hingga akhir penelitian.

Penelitian dilakukan pada siswa kelas IV di SDN Saptorenggo 02, Kecamatan Pakis, Kabupaten Malang, Jawa Timur. Waktu penelitian dilaksanakan pada tanggal 20-21 Januari 2020. Teknik pengumpulan data dilakukan dengan observasi, wawancara, angket, dan dokumentasi. Observasi merupakan kegiatan awal untuk mengetahui kendala dalam pembelajaran, sehingga peneliti dapat memperbaiki kendala tersebut dengan melakukan uji coba. Lembar observasi yaitu alat bantu dalam pengumpulan data mengenai kondisi lapangan secara langsung. Lembar observasi berisikan penerapan pembelajaran menggunakan model kooperatif tipe Talking Stick.

Observasi dilakukan di SDN Saptorenggo 02 Pakispada kegiatan belajar, di mana salah satu mahasiswa magang menerapkan model pembelajaran Talking Stick. Observasi kegiatan awal digunakan untuk mengetahui alasan dari munculnya hambatan Talking Stick. Oleh karena itu, diharapkan penelitian ini mampu menyelesaikan hambatan yang terjadi di model Talking Stick tersebut.

Kegiatan wawancara dilakukan kepada salah satu guru kelas IV SDN Saptorenggo 02 Pakis. Tujuan wawancara adalah untuk menyatukan pikiran berkaitan dengan hambatan yang diamati peneliti dengan pikiran dari guru yang telah menerapkannya. Kegiatan wawancara dilakukan secara terstruktur. Wawancara dilakukan peneliti di SD pada tanggal 17 Januari 2020. Pengajuan pertanyaan tersebut untuk mengetahui penerapan model Talking Stick dan penyampaian materi tari Bungong Jeumpa yang dilakukan oleh guru. Setelah melakukan wawancara, pengembangan model Talking Stick diujicobakan untuk mengetahui pengembangan dari model tersebut.

Pengambilan data melalui angket bertujuan untuk mengetahui pengembangan model pembelajaran Talking Stick. Angket yang digunakan berupa angket respon guru dan angket respon peserta didik. Angket yang diberikan kepada guru dan peserta didik bertujuan untuk mengetahui pengembangan yang dilakukan peneliti. Dalam angket berisikan penilaian, kritik, dan saran dari guru dan peserta didik untuk peneliti. Terdapat juga angket validasi ahli model, ahli materi dan media guna untuk memberikan penilaian dan saran atau komentar berkaitan dengan produk yang dikembangkan. 
Teknik pengumpulan data dokumentasi adalah untuk melengkapi data dari hasil implementasi pengembangan melalui permainan dan foto terkait pelaksanaan pada implementasi.

\section{Hasil dan Pembahasan}

Model pembelajaran merupakan sintaks atau langkah-langkah yang mengatur jalannya pembelajaran. Model adalah suatu konsep yang memiliki struktur secara terarah dan mencangkup empat bentuk, antara lain konseptual, prosedural, visual, dan persamaan (Atwi, 2014). Penerapan pengembangan model pembelajaran Talking Stick melalui permainan Truth or Dare pada materi seni tari yaitu tari Bungong Jeumpa pada mata pelajaran Seni Budaya dan Prakrya (SBdP). Pembelajaran dengan menggunakan permainan merupakan suatu bentuk pembelajaran yang dapat mendorong motivasi belajar siswa dan pengalaman siswa secara langsung.

Model pembelajaran memiliki dua cakupan, yaitu model pembelajaran secara individu dan model pembelajaran secara berkelompok. Model pembelajaran secara berkelompok memiliki beberapa tipe, salah satunya model pembelajaran berkelompok tipe Talking Stick. Talking Stick berarti tongkat yang berbicara, maksudnya dalam penggunaanya model pembelajaran yang menggunakan bantuan dari tongkat (Huda, 2015). Kelompok atau peserta didik yang memegang tongkat akan menjawab pertanyaan dari guru berkaitan dengan materi yang telah mereka pelajari. Kegiatan itu diulang terus-menerus sampai setiap kelompok mendapatkan giliran dari tongkat untuk menjawab pertanyaan dari guru. Adanya penggunaan variasi model pembelajaran membuat proses belajar lebih menyenangkan.

Saat proses penerapan, peneliti menyiapkan pengembangan model Talking Stick dan permainan Truth or Dare. Peneliti menyampaikan tujuan pembelajaran berkaitan dengan materi seni tari yaitu tari Bungong Jeumpa.bKemudian, peneliti membagi menjadi 4 kelompok untuk mempraktikkan tari Bungong Jeumpa, seperti yang tergambar pada Gambar 7.

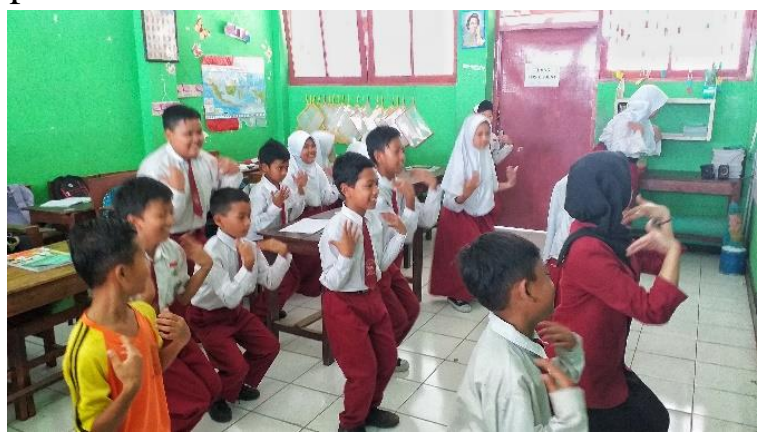

Gambar 7 Guru sebagai Fasilitator (Sumber: Dokumentasi Penulis, 2020)

Pengembangan model pembelajaran Talking Stick materi tari Bungong Jeumpa dilakukan berdasarkan model penelitian ADDIE untuk mengetahui dan mendeskripsikan pengembangan. Melalui validasi ahli model yang dilakukan oleh Ibu Ima Wahyu Putri Utami., S.Pd., M.Pd, ahli materi yang dilakukan oleh validator Ibu Belinda Dewi Regina., S.Pd., M.Pd dan ahli media Ibu Beti Istanti Suwandayani., S.Pd., M.Pd serta hasil dari respon guru Bapak Riza Andrian., S.Pd. Gr dan siswa kelas IV menunjukkan pengembangan ini dapat meningkatkan minat dan proses pembelajaran tari tradisional kepada siswa.

Berdasarkan hasil respon guru dan siswa setelah menggunakan Pengembangan Model Pembelajaran Talking Stick Melalui Permainan Truth or Dare pada Materi Tari Bungong Jeumpa Terhadap Siswa Kelas IV Sekolah Dasar bahwa pengembangan yang dilakukan sangat membantu dalam proses pembelajaran. Hasil angket respon siswa yang berjumlah 19 siswa, 13 siswa memilih sangat layak untuk digunakan, 2 siswa memilih layak digunakan, dan 4 siswa memilih cukup layak untuk digunakan. Hasil angket respon guru menyatakan sangat layak untuk digunakan dalam pembelajaran. Hal ini selaras dengan pernyataan guru hendaknya mengembangkan aksi pedagogisnya dengan anak-ana pada usia rentang nol hingga lima tahun. Hal ini karena anak-anak berada pada fase kehidupan di mana anak belajar sangat cepat untuk berkomunikasi dengan 
lingkungan. Hal ini sejalan dengan pemikiran Agamben bahwa asumsi yang mengandaikan masa kecil sebagai zat psikis prasubyektif dan subjek pra-linguistik hanyalah mitos (Agamben, 1982). Hal ini karena masa kanak-kanak adalah asal mula bahasa dan bahasa adalah asl mula masa kanak-kanak (Setiawan, 2018).

Berdasarkan hal tersebut, maka pengembangan ini berhasil dilakukan dan diterapkan pada pembelajaran seni budaya siswa sekolah dasar. Proses pembelajaran hendanya juga memperhatikan cara untuk menarik minat siswa untuk tertarik dan menaruh minat dalam belajar melalui caracara yang juga dekat dan disukai oleh anakanak (Hidayah, 2019).

\section{Kesimpulan}

Berdasarkan penelitian yang dilakukan tampak bahwa inovasi model pembelajaran Talking Stick dengan permainan truth or dare yang memanfaatkan media dadu dalam pembelajaran tari Bungong Jeumpa pada siswa Sekolah Dasar 02 Saptorenggo Pakis mampu meningatkan minat dan hasil pembelajaran. Berdasarkan hal tersebut hendaknya hasil penelitian ini dapat menjadi acuan bagi guru untuk diterapkan atau menjadi inspirasi bagi pengembangan model pembelajaran lain yang menyenangan bagi peserta didik.

\section{Daftar Pustaka}

Agamben, G. (1982). Language and Death: The Place of Negativity (M. H. Karen E. Pinkus Ed.). Minneapolis: University of Mennesota Press.

Ahmadi. (2014). Pengajaran dan Kependidikan: Remaja Rosdakarya.

Arisyanto, P., Sundari, R. S., \& Untari, M. F. A. (2018). Pembelajaran Ekstrakurikuler Tari Untuk Penanaman Karakter Bagi Siswa SD Negeri Gayamsari 02 Semarang.
JPKS (Jurnal Pendidikan dan Kajian Seni), 3(1).

Atwi, S. (2014). Panduan Para Pengajar dan Innovator Pendidikan. Jakarta: Erlangga.

Hamzah. (2013). Belajar Dengan Pendekatan PAIKEM. Jakarta: Bumi Aksara.

Hidayah, F. N. (2019). Pengembangan Modul Tari Kreasi Daerah untuk Meningkatkan Hasil Belajar Tari Guci Pada Siswa Kelas V SDN Jembayat 03 dan SDN Jembayat 06. (Doctoral), Universitas Peradaban,

Huda, M. (2015). Model-Model Pengajaran dan Pembelajaran. Yogyakarta: Pustaka Pelajar.

Nurkholis. (2013). Pendidikan dalam Upaya Memajuan Teknologi. Jurnal Kependidikan, 1(1), 24-44. doi:https://doi.org/10.24090/jk.v1i1. $\underline{530}$

Permanasari, A. T., Lestari, D. J., \& Fujiawati, F. S. (2018). Penerapan Pembelajaran Tari Untuk Anak Usia Dini Dalam Mengembangkan Kreativitas Mahasiswa Jurusan Pendidikan Sendratasik Untirta. JPKS (Jurnal Pendidikan dan Kajian Seni), 3(2), 135-148. doi:10.30870/jpks.v3i2.6916

Priyani, P. (2019). Apresiasi Seni Tari Bungong Jeumpa. Retrieved from https://idoc.pub/documents/2makalah-apresiasi-seni-taribungong-jeumpa-vlr9xqomkplz

Restian, A. (2016). Pelatihan Guru Seni Tari Tradisional SD Muhammadiyah 8 Dau Malang. Retrieved from Malang:

Setiawan, A. (2018). Problematika Pembelajaran Seni Tari Di TK Candra Kirana Surabaya. Pedagogi: Jurnal Anak Usia Dini dan 
Pendidikan Anak Usia Dini, 3(1), 111.

Sunaryo, H., Andalas, E. F., Putra, C. R., \& Asrini, H. W. (2018). Penggalian Ide Melalui Pengembangan Berfikir Kritis Berdasarkan Gambar Bertema dalam Pembelajaran Menulis Cerpen. Literasi, 8(2), 50-57.

Sundari, R. S. (2016). Pengembangan Kepribadian dalam Pembelajaran Seni Tari di Sekolah. Imajinasi: Jurnal Seni, 10(1), 61-66.

Susilana, R. (2014). Pendekatan Saintifik dalam Implementasi Kurikulum 2013 Berdasarkan Kajian Teori Psikologi Belajar. Jurnal Educational Technology, 13(2), 183-193. doi:10.17509/edutech.v13i2.3095.g2 119 